\title{
OBSTACLES TO DEVELOPMENT OF GAYO ARABICA COFFEE COMMODITY IN BENER MERIAH REGENCY
}

\author{
Emmia Tambarta Kembaren1); Nola Windirah2) \\ 1) Lecturer of Agribusiness Department, Agriculture Faculty, Malikussaleh University. \\ 2) Lecturer of Agribusiness Department, Faculty of Agriculture, University of Bengkulu \\ Email: ${ }^{1)}$ emmia.tambarta@unimal.ac.id ; ${ }^{2)}$ nolawindirah@unib.ac.id
}

\section{How to Cite :}

Kembaren, E. M., Windirah, Nola. 2021. Obstacles To Development Of Gayo Arabica Coffee Commodity In Bener Meriah Regency. Journal of Agri Socio Economics and Business. 03 (2): 99-108. DOI: https://doi.org/10.31186/jaseb.03.2.99-108

\section{ARTICLE HISTORY \\ Received [03 Sept 2021] \\ Revised [08 Nov 2021] \\ Accepted [21 Nov 2021]}

\section{KEYWORDS}

Obstacles, Arabica Coffee, USG,

This is an open access article under the $C C-B Y$-SA license

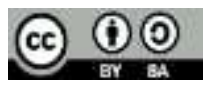

\section{ABSTRACT}

Coffee has great potential to be developed in Indonesia because of its large role in increasing the country's foreign exchange through export activities. Bener Meriah Regency, Aceh Province, is one of the main producing areas of Arabica coffee. The development of Arabica coffee commodities in Bener Meriah is still not optimal due to the findings of various problems such as post-harvest handling cultivation systems, technology, to marketing conditions that continue to change according to global conditions. This problem causes Bener Meriah Arabica coffee to not be optimal in contributing to regional income, employment and contributing to coffee farmers' household income. In the previous research, only one aspect highlighted, so the findings to overcome these problems have not been optimal. Through the analysis of Urgency, Seriousness, Growth (USG), this research will find a solution formed in stages of solving the problems experienced by Arabica coffee farmers, starting from the upstream to the downstream process. The results of the study show that the constraints on trade conditions that have changed after the Pandemic are the main problems that must be resolved first in Bener Meriah Regency. The second problem that must be resolved is extreme climate change. The third is post-harvest handling and the fourth is the high cost of transportation. 


\section{INTRODUCTION}

Indonesia has a comparative advantage in the development of agricultural commodities. Indonesia is rich in terrestrial and aquatic biodiversity, has a tropical climate, has fertile and extensive land. Indonesia's natural resources can produce large amounts of agricultural commodity products. In addition, Indonesia currently has social capital such as farmer institutions, human resources (HR) and sufficient infrastructure to develop the agricultural sector. The increase in Indonesia's foreign exchange/economics can be achieved by integrating agricultural development (including plantations, livestock, fisheries, forestry) with the development of upstream and downstream agricultural industries and related service sectors (Saragih, 2001).

One of the agribusiness commodities that have the potential to be developed in Indonesia is coffee. This agricultural commodity has an important role in the Indonesian economy, namely as one of the export commodities that generate foreign exchange for the country beside oil and gas. Coffee plants are also one of the mainstay commodities in Aceh. Coffee originating from Aceh is better known as Gayo coffee. This is because the three main coffee producers in Aceh are located in the Gayo highlands as shown in the following graph:



Graph 1. Coffee Producers In Aceh Source: BPS, 2020

The data shows that Bener Meriah Regency is one of the main Arabica coffee producing areas in Aceh. This commodity has a high economic value and plays an important role as a source of regional income, absorbs labor and contributes to farmers' income in Bener Meriah Regency. This area has a great natural resources to develop plantation crops such as arabica coffee, and horticultural crops such as 100 | Kembaren, E. M., Windirah, Nola. Obstacles To Development Of Gayo... 
cabbage, potatoes, tomatoes, carrot, tamarillo, chilies, oranges and marquisa (BPS Aceh, 2020).

The development of Arabica coffee commodities in Benar Meriah is still not optimal. This happens because of various obstacles in the coffee management sector such as cultivation systems, post-harvest handling, technology, to marketing conditions that continue to change according to global conditions. Various studies on coffee commodities have been carried out, but most of them only focus on one aspect, such as in the field of cultivation, processed products and institutions partially. Studies related to the constraints on the coffee sector from upstream to downstream in a comprehensive manner are still not widely developed. It is important to map the constraints on the coffee commodity development process as a basis for developing other research studies, such as mapping strategies to develop coffee commodities so that it can compete in all conditions, such as the free trade system, the Covid 19 pandemic, or other external problems.

\section{RESEARCH METHODS}

This research was conducted in Bener Meriah Regency as one of the main Arabica coffee producing areas in Aceh. The research method used is descriptive qualitative method. The data used in this study are primary data and secondary data. Primary data was conducted by conducting FGDs with 15 participant whose directly involved in the development process of gayo arabica coffee such as farmers ( 6 person), representatives of the coffee processing industry (3 person), the Department of Agriculture and food (3 person), and the Trade Department of Bener Meriah Regency (3 person). While secondary data obtained from literature study of data on the relevant agencies. The results of the study were analyzed using the Urgency, Seriousness Growth (USG) analysis tool which is a tool for arranging the priority order of obstacles to find out which obstacles must be resolved first (Kotler, 2014). USG will produce the level of urgency, seriousness, and progression of the problem with a Likert scale. The issue that has the highest total score is a priority obstacle. The use of USG to answer the issue of obstacles to the development of gayo arabica coffee commodities in Bener Meriah Regency uses USG assessment indicators consisting of:

1. Urgency: How urgently the issue must be discussed, analyzed and followed up.

2. Seriousness: How serious the issue must be discussed is related to the consequences.

3. Growth: How likely is the issue to get worse if it is not handled properly. (Kotler et al, 2014)

The USG assessment was carried out using values ranging from 1 to 5 (Likert scale). The more obstacles with the highest scoring indicate that these obstacles are very important and very serious to be solved immediately. Several studies using the USG method include Riswanto (2016), Santoso (2017), Ariyanti et al (2020), and Utari and Wahyuni (2020). 


\section{RESULTS AND DISCUSSION}

Coffee plants are one of the mainstay commodities in Aceh. Coffee originating from Aceh is better known as Gayo coffee. This is because the three main coffee producers in Aceh are located in the Gayo highlands. Gayo coffee is one type of Arabica coffee that is in great demand in international trade because it has a distinctive aroma and taste. The climatic conditions and soil types in this district are very suitable for cultivating arabica coffee plants. Arabica coffee is also an important commodity for the community's economy and is an important commodity that can increase regional income, absorb labor and contribute to farmers' income in Bener Meriah Regency.

Gayo Arabica coffee is also one of the most popular Arabica coffees in the international market. The taste test results (cupping test) for the export of gayo arabica coffee commodities are more than 80 on average of cupping score scale base on SCAA (International standart of coffee quality). This shows that gayo arabica coffee has a distinctive taste and good body viscosity. The price of Gayo Arabica coffee is also higher when compared to Robusta coffee. However, this potential is not followed by good system of the development conditions. This is because of the various obstacles that occur in the process of developing the coffee commodity. The Obstacles of gayo arabica coffee in Bener Meriah Regency which obtained from Focus Group Discussion activity with 15 participant can be seen in the following table:

Table 1. The results of USG analysis of the obstacles on the development of gayo arabica coffee in Bener Meriah Regency

\section{Issues}

$\begin{array}{llll}\text { U } & \text { S } & \text { G } & \text { Ranking }\end{array}$

Extreme climate change and suboptimal handling of cultivation have resulted in low productivity of coffee plantations.

Post-harvest handling that has not been optimal, resulting in Gayo Arabica coffee products that do not meet international standards

The trading conditions for Gayo Arabica coffee have changed after the Covid 19 Pandemic.

5

$\begin{array}{lll}5 & 5 & 4\end{array}$

There is no direct transportation system from Aceh to export destination countries, which causes high transportation costs.

The condition of the coffee commodity sector in Bener Meriah Regency is currently facing a decline in productivity both in quantity and quality due to climate change. The productivity of arabica coffee in Bener Meriah Regency only reaches 700 $\mathrm{kg}$ per hectare of coffee plantations. The climate is changing drastically as there is an increase in temperature and an increase in the amount of rainfall at uncertain times. Extreme weather changes cause the intensity of rainfall and the intensity of the sun's heat can no longer be predicted. This condition can cause damage to coffee plants. This is in line with research by Khalisuddin (2012) which states that changes in

102 | Kembaren, E. M., Windirah, Nola. Obstacles To Development Of Gayo... 
temperature will cause serious effects on coffee production so that it will be very difficult to maintain the level of coffee productivity (Khalisuddin et al. 2012).

The low productivity of the Gayo Arabica coffee commodity is also caused by the handling/system of coffee cultivation that does not follow the Good Agricultural Practices (GAP) system. The management of the GAP cultivation system includes the selection of superior coffee planting materials, maintenance, crop pruning, and providing shade, pest and weed control, fertilization without excessive chemicals, and harvesting according to national/international standards. The international standard for coffee cultivation systems is organic farming systems.

This system applies good cultivation practices by not allowing farmers to use genetically engineered (GMO) seeds, using organic fertilizers (non-chemical), and not using chemical pesticides so as to improve quality and preserve the environment. This cultivation system is characterized by organic certificates received by farmers from international trade parties such as exporters or product quality assurance institutions in the world. This certification is usually carried out by regulating the cultivation system starting from nurseries, land preparation, garden management, harvesting and postharvest management. The principle is to emphasize the prohibition of the use of chemicals that can threaten food safety (product quality) and the importance of preserving the environment.

The coffee cultivation system in Bener Meriah Regency is still dominated by nonorganic agriculture. Coffee farmers stated that it was very difficult to eradicate pests and diseases of coffee plants without the help of chemical pesticides. The absence of organic pesticide products is one of the main reasons for farmers to use chemical pesticides. Attacks from various pests and diseases will also reduce the productivity and quality of the coffee beans produced. This obstacle also occurs due to the lack of knowledge of farmers regarding the manufacture of organic pesticides. Another cultivation problem is that most of the coffee farmers in Bener Meriah Regency still have not mastered the ability of a good harvesting system, namely the red logs that are picked are really bright red logs.

The harvesting process is mostly carried out by day laborers who pursue quantity targets so they tend to pick cherry beans at random. As a result, many young seeds (Quacker) or ripe seeds (rotted) are also harvested. Quacker beans and beans that are too ripe will reduce the quality and taste of coffee products. Young seeds will produce a taste like green grass / straw / or weed which is very unpleasant on the tongue, while overripe seeds will produce a sour taste that is too excessive (over fermented). Both of these things will reduce the quality of the coffee beans and the score on the cupping test.

This obstacle has a score of 4 on the urgency indicator, 5 on the Seriousness indicator and 5 on the growth indicator with USG. This means that if this problem is not addressed as soon as possible, it will become an inhibiting factor in the process of developing the Gayo Arabica coffee commodity. Climatic constraints and handling of the cultivation system are closely related to the quality and grade of the coffee products to be produced. If these problems are not repaired effectively, the grade and product quality will continue to decrease.

The second obstacle in the development sector of Gayo Arabica coffee is the quality of Gayo Arabica coffee products that do not meet international standards. One of the main causes of the low quality of coffee products other than the cultivation 
system is the post-harvest handling factor that is less than optimal. This is in line with research by Tambarta (2016) and Bagio (2021) which state that one of the weaknesses of gayo arabica coffee commodities is the low quality of gayo arabica coffee in the international market. This obstacle is caused by the existence of a cultivation and postharvest processing system for Arabica coffee beans that does not meet the international standards (Tambarta et al., 2016; Bagio et al., 2021)).

Good post-harvest handling is only carried out by large cooperatives that have received international certifications such as fair trade and organic certificates. The outside processing industry has not yet applied the principle of good handling product. Good handling products starts from the handling of the harvest/results of red logs that meet standard operating procedures (SOP), which must be done in the correct sorting manner (sorted red logs are really bright red logs), proper pulping time less than 18 hours, the right method and time for washing coffee grain, as well as drying and storing hygienic grain.

The coffee bean drying system in this area still uses manual technology where coffee beans are dried using blue tarpaulin on the asphalt in front of the house or the nearest drying field. The handling of this drying system greatly affects the taste of Gayo Arabica coffee itself. If gayo arabica coffee beans are contaminated with soil and dust, it will cause an "earthty" taste when the cupping test is carried out. This type of taste is a disturbing variable in the taste of coffee which will reduce the quality value of Arabica coffee itself.

In addition, post-harvest handling of coffee in Bener Meriah Regency is also still dominated by semi-modern technology that is not in accordance with international food safety standards. Semi-modern technology mostly uses human power and uses little machine technology. This condition will affect the processing of Gayo Arabica coffee beans. The use of coffee tools and technology in this area is still not in accordance with the current 4.0 era standards. On the other hand, coffee producing countries such as Brazil and Vietnam continue to compete to develop technology and innovation in their coffee sector.

This obstacles has a score of 4 on the urgency indicator, a score of 5 on the Seriousness indicator and a score of 4 on the growth indicator using USG. This obstacle has a high level of seriousness but the level of urgency is still below the first problem. This is because the first obstacles is basic and interrelated with the second obstacles. Cultivation system obstacles must be resolved first to produce good cherry beans for processing into semi-finished products or final products. If this problem is not addressed as soon as possible, it will hinder the process of developing the Gayo Arabica coffee commodity.

Furthermore, Indonesia is currently facing the global COVID-19 pandemic. This condition resulted in the emergence of obstacles to various changes in the trading system such as shifting product quality parameters, the imposition of regional restrictions or lock downs in several export destination countries and social distancing regulations between individuals. This is in line with Fadli's (2021) research which states that the COVID-19 pandemic is certainly a challenge that will create various marketing obstacles for Gayo Arabica coffee, such as changes to the coffee processing system that must comply with COVID handling protocols, new product packaging procedures and an online cooperation system due to the implementation of social distancing regulations (Fadli et al., 2020). 
There is a shift in quality parameters after the covid pandemic which leads to global food hygiene and safety from processing. This additional parameter will certainly complicate the development of gayo arabica coffee commodities in Bener Meriah Regency. This is because this area is still not well prepared to process coffee products hygienically. Most of the Arabica coffee cultivation systems still use chemical fertilizers and pesticides, the washing system still uses the semi-washed method, and the drying system still uses traditional technology. These three things will certainly be very contrary to the parameters of hygiene and food safety globally.

During the COVID-19 pandemic, several destinations for Indonesian coffee exports experienced such severe impacts that they imposed regional restrictions or lock downs, either partially or completely. One of the restricted activities is export and import transactions of goods and services from affected countries. This regional restriction creates obstacles in the difficulty of licensing transportation between Indonesia and the destination country. Various gayo arabica coffee entrepreneurs have experienced difficulties in sending coffee from March 2020 to January 2021. This causes the coffee beans to accumulate in coffee farmers because they cannot be traded to export destination countries. Coffee beans harvested by coffee farmers have to be piled up in the warehouses of coffee entrepreneurs.

On the other hand, farmers continue to be pressured because of the high cost of harvesting and other costs, while coffee beans cannot be exported because of the lock down rule. The number of gayo arabica coffee beans available in Bener Meriah Regency causes a decrease in Arabica coffee prices which results in a decrease in the level of welfare of coffee farmers. The current decline in coffee prices is quite significant. The price of Gayo Arabica coffee usually reaches Rp. 90.000, - in normal times, but decreased to Rp. 40,000,- at this point.

Trade conditions that have also changed due to the COVID-19 pandemic are the implementation of social distancing regulations and vaccination certificates for every individual who will visit other regions/countries. Before the COVID19 pandemic, coffee buyers were free to come and see directly the coffee processing activities at several coffee businesses/factories in Bener Meriah. This will certainly help farmers and entrepreneurs to attract international market interest. However, since the COVID-19 pandemic, this activity is very limited. Some buyers even have to carry out various health procedures such as mandatory swab tests before leaving for Indonesia, being required to wear masks, and being obliged to keep their distance when they arrive in Indonesia. Some countries do not even allow their citizens to leave the country. This of course will greatly affect the pattern of promotion of Arabica coffee beans itself.

The obstacle to trading conditions for Gayo Arabica coffee, which has changed after the Covid 19 Pandemic, has a score of 5 in the urgency indicator, a score of 5 on the Seriousness indicator and a score of 5 on the growth indicator using the USG tool. This shows that this obstacle is the main obstacle that must be resolved immediately in Bener Meriah Regency. These obstacles are urgent to be discussed, analyzed and followed up. If this obstacle is not followed up immediately, the development of coffee commodities will certainly be greatly hampered. The possibility of developing this problem if it is not immediately resolved is also quite high, which means that if this problem is not immediately resolved it will greatly reduce the welfare of gayo arabica coffee farmers in Bener Meriah Regency. The decline in welfare will certainly cause the motivation of farmers to develop coffee commodities to decrease. Parties involved in 
the development of coffee commodities must immediately find a solution to resolve this problem.

The next obstacle that also affects the development of gayo arabica coffee beans is the absence of a direct transportation system from Aceh to export destination countries which causes large transportation costs. So far, the process of sending Arabica coffee to export destination countries always has to go through Belawan Port in North Sumatra Province. This will certainly increase the cost of transportation to North Sumatra Province. On the other hand, Aceh Province itself actually has the Krueng Geukueh port which can be used to send coffee to various export destination countries. This obstacle got a score of 4 on the urgency indicator, 4 on the Seriousness indicator and 4 on the growth indicator with USG. This means that this obstacle is not less urgent, serious and has an impact on the development of Arabica coffee commodities. However, the level of urgency is not as high as some of the other issues.

\section{CONCLUSIONS AND POLICY IMPLICATIONS}

\section{Conclusions}

The obstacles of the Gayo Arabica coffee trade condition which has changed after the Covid 19 Pandemic is the main obstacle that must be resolved immediately in Bener Meriah Regency. This obstacles has the highest score in USG analysis. This obstacle is considered urgent to be discussed, analyzed and followed up. If this obstacle is not followed up immediately, the development of coffee commodities will certainly be greatly hampered. The second obstacle, based on USG analysis, is the extreme climate change and sub-optimal handling of cultivation, which causes low productivity of coffee plantations. Climatic constraints and handling of the cultivation system are closely related to the quality and the grade of the coffee products to be produced. If these problems are not repaired effectively, the quality and product quality will continue to decline.

The third obstacle is the post-harvest handling that is not optimal, resulting in Gayo Arabica coffee products that do not meet international standards. This constraint has a close relationship with the constraints of handling cultivation that is not optimal. Cultivation system constraints must be resolved first to produce good cherry beans for processing into semi-finished products or final products. If this problem is not addressed as soon as possible, it will hinder the process of developing the Gayo Arabica coffee commodity. The constraint of the absence of a direct transportation system from Aceh to export destination countries which causes the high transportation costs also has an impact on the development of Arabica coffee commodities. However, the level of urgency, excitement and potential for the development of the problem is not as high as other obstacles.

\section{Recommendations}

1. Some of the policy recommendations that the author has compiled are as follows::Extreme climate change constraints can be solved by conducting research on Arabica coffee plant varieties that are resistant to extreme climate change. This research can be carried out by academics/scientists who have a scientific background in the field of plant breeding. Bener Meriah Regency independently has a gayo experimental garden institution that can be used as a forum for 
research related to the development of varieties that are resistant to these extreme climates.

2. Obstacles in the post-harvest handling process that are not yet optimal can be resolved by the existence of regulations to build a system of warehousing, washing, and drying places with post-harvest technology that is modern, environmentally friendly, and can be accessed by coffee farmers.

3. The conditions of regional enforcement and social distancing can be overcome by providing effective digital promotion facilities that can be reached by farmers in this area. Direct promotions/visits of foreign buyers can be replaced with visits via digital/online technology.

4. The problem of the absence of direct transportation facilities for coffee delivery to export destination countries can be overcome by submitting an application for the use of the Krueng Geukueh port for direct coffee shipments to export destination countries by decision makers in Aceh Province.

\section{REFERENCES}

Ariyanti, N. S., Adha, M. A., Sumarsono, R. B., Sultoni. (2020). Strategy to Determine the Priority of Teacher's Quality Problem Using USG (Urgency, Serioueness, Growth) Matrix. IRBEJ, 2(2), 54-62.

Bagio, Tambarta, E., Fadli, Suryadi. (2021). Strategi Pengembangan Bubuk Kopi Gayo di Kabupaten Aceh Tengah. Jurnal Agrisep, 22(1), 63-72.BPS Aceh, 2020. Provinsi Aceh Dalam Angka. BPS Provinsi Aceh, Aceh.

Daryanto, A., Fadillah, A., Salsabila, Y. N., 2019. Marketing Strategy Analysis Kopi Arabika Speciality (Studi Kasus Pada CV Frinsa Agrolestari). Jurnal Ilmiah Manajemen Fakultas Ekonomi,5(1), 1-14.

Fadli, Suryadi, Tambarta, E., 2020. Kendala Pemasaran Kopi Arabika Pada Masa Pandemi Covid 19 Di Aceh Tengah. J. bisnis tani 6, 115-122.

Fasya, T.K,. 2018. Egalitarianisme Gayo. Aceh Anthropological Journal, 2(2), 1-19.

Juventa, P. A., Lestari, N., Harbiyah, S., 2021. Peran Corporate Secretary Membangun Kembali Reputasi PerusahaanStudi Kasus Karyawan PT Istaka Karya. Jurnal Komunikasi, 6(1), 27-42.

Khalisuddin, Setyantoro AS, Gayosia AP, Bahany N, Bathin WR. 2012. Kopi dan Kehidupan Sosial Budaya Masyarakat Gayo. Balai Pelestarian Nilai Budaya: Banda Aceh

Kotler, P., Amstrong, G., 2014. Principles of Marketing., 15th ed, Pearson Pretice Hall. Pearson Pretice Hall, New Jersey. https://doi.org/10.2307/2548367

Lourensia. F., Setiyanto. Y., 2018. Peran Public Relations dalam Memulihkan Reputasi ( Studi Kasus Manajemen Krisis PT Kereta Commuter Indonesia Pasca Perubahan Sistem E-Ticketing).PROLOGIA,2(2),327-333.

Mayamsari, I., Kembaren, E. K., Bagio., 2021. 94. Analysis Of Added Value Of Organic Certified Premium Arabica Coffee Beans And Organic Certified Premium Arabica Coffee Beans In Central Aceh.Journal of Agribusiness Sciences, 4(2), 94-99.

Riswanto, A. (2016). Kemiskinan: Faktor Penyebab dan Analisis Pemecahan Masalah.Jurnal Sosial Humaniora, 7(1), 59-72.

Santoso, A. C. (2017). Strategi Pemasaran dengan Mengurangi Komplain Konsumen Pada UKM SKD. Prosiding Seminar Nasional Multi Disiplin Ilmu, 3, 151-158. 
Santoso, B., Akbar, M., Lestari, S., 2020. Supervision Strategy in Improving Teacher Quality at Universitas Islam.Jurnal Iqra' Kajian Pendididkan,5(2),2527-4449. As-Syafi'iyah

Saragih, B., 2001. Pembangunan Sistem Agribisnis Di Indonesia Dan Peranan Public Relation, in: Seminar Peranan Public Relation Dalam Pembangunan Pertanian. Bogor, pp. 1-12.

Sari, P.A,. 2018. Analisi permasalahan petani tanaman kopi rakyat di pangalengan dengan mengadaptasi Theory of Change. Jurnal Dharma Bhakti Ekuitas,2(2),2528-2190.

Sudiartha, G.M,. Sari, I.G.A.A.H., 2019. Pengendalian kualitas proses produksi kopi arabika pada UD.Cipta Lestari Di Desas Pujungan. Jurnal Manajemen, 8(4), 2495-2523.

Syahruddin,. Sanusi, A., Wasliman, I., Sauri, S., 2020. Supervision Strategic Management of School Heads In Improving Teacher Performance (Case Study at Cinta Kasih Tzu Chi Middle School, and Vianney Jakarta Middle School). Journal of Islamicate Studies, 3(1), 23-35

Tambarta, E., Tinaprilla, N., Adhi, A.K., 2016. Analysis Added-Value And Development Strategic of Gayo Coffe Products in Bener Meriah Aceh 5, 515-519. https://doi.org/10.21275/ART20162754

Taqwadin, D. K., Sulaiman, A. N., Akmal, S., Faudzan, I., 2019. Potensi Budaya Minum Kopi (Ngopi) dalam membangun kembali Koeksitensi masyarakat Aceh paskah konflik, Jurnal IImiah Islam Futura, 19(1), 86-102.

Utari, E., Wahyuni, I. (2020). Analisis Matriks USG (Urgency, Seriousness and Growth) Banten Mangrove Center Bagi Masyarakat Kelurahan Sawah Luhur Kecamatan Kaseman Kota Serang. Biodidaktika, 15(2), 31-42. 